\section{HOLDING THE BANK OF ENGLAND TO ACCOUNT}

MPs are becoming increasingly frustrated at what they see as the Bank of England's unwillingness to improve its corporate governance by demonstrating a willingness to examine its own performance and become more accountable. This was demonstrated recently on the first day of the report stage of the Financial Services Bill, when the House of Commons Treasury Committee took the highly unusual step of tabling a new clause. All but one of the committee members approved a new clause 1, which placed a duty on the Bank of England's Court of Directors to conduct retrospective reviews and make them available to Parliament. The clause, which was tabled on April 23, also required the court to publish its full minutes something the Bank's Monetary Policy Committee already does.

Treasury Committee chairman Andrew Tyrie went on the attack, pointing out that the Court's role is confined to process and it cannot examine the Bank's performance, or make any recommendations about any discovery it does make if it answers any questions. "It is astonishing that the Bank still has not conducted and published a review of its own performance during the 2007-08 crisis. The Financial Services Authority and the Treasury have both done this, enabling both to face up to weaknesses in organisation."

Mr Tyrie said that his committee's two "pretty reasonable" suggestions had encountered a wave of objections from the Bank, and he pressed the Financial Secretary to the Treasury, Mark Hoban, to reveal what the government intended to about the issues raised by new clause 1. Mr Hoban said the government wanted to see the court's minutes published and retrospective reviews put in place, and a brief exchange with Mr Tyrie followed over whether the government's commitment extended to requiring publication of the court's full minutes or a summary record of them. The response from Mr Hoban was that the minutes "should certainly be a very good summary, catching the thought processes that took place in the court and the issues that were debated." He said that the government would reconsider the matters raised by the Treasury Committee when the Bill went to the House of Lords, which was sufficient to persuade $\mathrm{Mr}$ Tyrie to withdraw his committee's amendment.

The Treasury Committee published a report last November (Accountability of the Bank of England, HC 874) which called for the Court to be transformed into "a leaner and more expert Supervisory Board" with the power to review Bank policies and conduct. The Board would be made responsible "for meeting reasonable requests for information by Parliament," and the report also wanted the Bank to publish indicators of financial stability so that its performance in meeting stability objectives could be assessed. Frustration at what it sees as the lack of attention

\section{Articles}

Towards a decentralised European Public Prosecutor's Office?

EU defence rights: how the system can be improved

Institute News

\section{Articles (cont'd)}

The concept of good faith in international investment disputes - the arbitrator's dilemma

Migration and human rights - challenges

and possibilities

being given by the government to the twin tasks of enhancing the role of the Court and making the Bank of England more open about its work led the committee to intervene directly at report stage of the Financial Services Bill.

The Bill introduces a number of reforms to strengthen the UK's financial regulatory structure, including establishment of the Financial Policy Committee within the Bank of England to oversee systemic risks; clarifying responsibilities between the Treasury and the Bank of England in the event of a financial crisis; and transferring responsibility for prudential regulation to the Prudential Regulation Authority, a subsidiary of the Bank of England. Financial regulation will not work successfully if the Treasury and the Chancellor of the Exchequer do not have confidence in the way the Bank is run. The Bank and the Treasury Committee cannot agree on how the Bank should be governed, and it is also apparent that the committee and the coalition do not see eye to eye on the matter either; when tabling the new clause to the Financial Services Bill Mr Tyrie described the government's position on the issues he raised as "off-beam." The issue of how the Bank of England should perform the enlarged role expected of it must be clarified, as it has a direct bearing on how the lines of responsibility and accountability should operate between the Bank, the Treasury and the Chancellor in times of financial difficulty.

- The Court of the Bank of England announced on May 21 that it had commissioned a set of three reviews into the Bank's performance to learn lessons from past experience in order to improve future performance.

\section{Julian Harris}

Deputy General Editor, Amicus Curiae

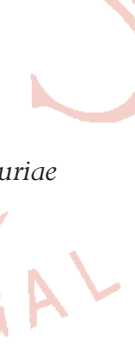

